\title{
DETERMINAN KEMATIAN NEONATAL DI RSUD SULTAN IMANUDIN PANGKALAN BUN
}

\author{
Riyanti ${ }^{1}$ Legawati $^{2}$ \\ Program Studi Diploma III Kebidanan Poltekkes Kemenkes Palangka Raya \\ Provinsi Kalimantan Tengah \\ Email : riyantihelena@gmail.com
}

\begin{abstract}
ABSTRAK
Upaya penurunan angka kematian neonatus dilakukan melalui berbagai upaya disetiap tatanan layanan kesehatan. Kematian neonatus disebabkan berbagai faktor baik langsung maupun tidak langsung. Penelitian ini bertujuan untuk mengetahui determinan penyebab kematian neonatus.

Pendekatan yang digunakan dalam penelitian ini observasional analitik dan rancangan Cross Sectional. Populasi pada penelitian ini adalah seluruh kematian neonatus yang terdapat di RSUD Sultan Imanudin Pangkalan Bun. Sampel penelitian berjumlah 103 orang BPM. Analisis univariat dilakukan dengan distribusi frekuensi, untuk analisis bivariat faktor Umur ibu, pendidikan, pekerjaan, paritas, tempat persalinan, status rujukan, penolong persalinan dan penyebab kematian menggunakan chi kuadrat $\left(\mathrm{x}^{2}\right)$. Hasil penelitian didapatkan bahwa kematian neonatus banyak terjadi pada kelompok neonatus dini 82 orang $(79,6 \%)$. Analisis bivariat menunjukkan bahwa faktor paritas dan penyebab $(p=0,001)$ menunjukkan pengaruh signifikan terhadap kematian neonatus. Simpulan hasil penelitian terdapat pengaruh paritas dan penyebab langsung maupun tidak langsung terhadap kematian neonatus.
\end{abstract}

Kata Kunci: Determinan, Kematian, Neonatal

\begin{abstract}
Efforts to reduce neonatal mortality are done through various efforts in every health care setting. Neonatal deaths are caused by various factors, either directly or indirectly. This study aims to determine of the cause of neonatal death.

The approach used in this research is analytic observational and Cross Sectional design. The population in this study is all neonatal deaths in RSUD Sultan Imanudin Pangkalan Bun. The sample of research is 103 people. Univariate analyzes were performed with frequency distribution, for bivariate analysis of factors Age of mother, education, occupation, parity, place of birth, status of referral, birth attendant and cause of death using chi square (x2). The results showed that neonatal mortality occurred in the early neonate group 82 people (79.6\%). Bivariate analysis showed that parity and cause factor $(p=0,001)$ showed significant influence to neonatal mortality. Conclusions of the study resulted in parity and direct or indirect causes of neonatal death.
\end{abstract}

Keywords: Determinant, Death, Neonatal 


\section{PENDAHULUAN}

Pembangunan kesehatan di Indonesia diarahkan untuk meningkatkan derajat kesehatan dan kualitas sumber daya manusia, terlihat melalui upaya meningkatkan usia harapan hidup, menurunkan angka kematian ibu dan anak, meningkatkan kesejahteraan keluarga, meningkatkan produktifitas kerja, serta meningkatkan kesadaran masyarakat untuk berperilaku hidup sehat (Kemenkes RI, 2014). Angka Kematian Bayi (AKB) merupakan indikator penting untuk menilai tingkat kesejahteraan masyarakat suatu negara dan status kesehatan masyarakat. Berdasarkan data United Nation 2010 bahwa 41\% kematian bayi terjadi pada usia neonatal dengan usia 0-28 hari. Angka Kematian Neonatus (AKN) pada tahun 2012 sebesar 19 per 1000 kelahiran (SDKI,2012)

Salah satu faktor penting dalam upaya penurunan angka kematian tersebut yaitu penyediaan pelayanan kesehatan neonatal yang berkualitas baik terhadap masyarakat, tetapi sekarang belum dapat terlaksana dengan baik. Untuk itu pemerintah mencanangkan Making Pregnancy Safer (MPS), yang pada dasarnya menekankan pada penyediaan pelayanan kesehatan neonatal yang costeffective, yaitu pertolongan persalinan oleh tenaga kesehatan, penanganan komplikasi obstetri dan neonatal, serta pencegahan kehamilan tidak diinginkan dan penanganan komplikasi abortus (Depkes RI, 2011). Masa neonatal merupakan masa yang sangat rentan karena penyesuaian diri dari kehidupan dalam rahim kepada kehidupan diluar rahim. Kejadian kematian pada neonatal sangat ditentukan oleh kualitas pelayanan kesehatan yang dipengaruhi juga oleh kondisi kesehatan ibu yang jelek, perawatan selama kehamilan yang tidak adekuat, penanganan selama persalinan yang tidak tepat dan tidak bersih, serta perawatan neonatal yang tidak adekuat. Penurunan angka kematian neonatal dapat dicapai dengan memberikan pelayanan kesehatan yang berkualitas dan berkesinambungan sejak bayi dalam kandungan, saat lahir hingga masa neonatal dengan upaya bersama tenaga kesehatan dengan melibatkan dukun bayi, keluarga dan masyarakat. Untuk mengukur keberhasilan penerapan intervensi yang efektif dan efisien, dapat dimonitor melalui indikator cakupan pelayanan yang mencerminkan jangkauan dan kualitas pelayanan kesehatan bayi baru lahir.Pada tahun 2012 Kementerian Kesehatan meluncurkan program Expanding Maternal and Neonatal Survival (EMAS) dalam rangka menurunkan angka kematian ibu dan neonatal sebesar $25 \%$ yaitu dengan cara meningkatkan kualitas pelayananan emergensi obstetri dan bayi baru lahir minimal di 150 rumah sakit (PONEK) dan 300 Puskesmas/Balkesmas (PONED) dan memperkuat sistem rujukan yang efisien dan efektif antar Puskesmas dan rumah Sakit. Berbagai upaya telah dilakukan 
pemerintah dalam rangka menurunkan angka kematian neonatus, berbagai faktor masih menjadi kendala terutama di daerah yang akses pelayanan kesehatan masih kurang. Faktor penyebab langsung dan tidak langsung sangat perlu ditelaah secara kontinu sehingga dapat segera ditanggulangi dalam upaya menurunkan kematian neonatus.

\section{METODOLOGI}

Jenis penelitian ini adalah penelitian deskriptif analitik dengan rancangan cross sectional. Populasi penelitian seluruh kematian neonatal tahun 2014-2015 di RSUD Sultan Imanudin Pangkalan Bun yang berjumlah 103 kematian. Cara pengambilan sampel pada penelitian ini adalah dengan menggunakan probability sampling dengan teknik Simple Random sampling

\section{HASIL DAN PEMBAHASAN}

Penelitian ini dilakukan pada sampel yang memenuhi kriteria inklusi dan ekslusi. Hasil penelitian terdapat pada table berikut:

Tabel 1. Perbandingan karakteristik kasus Pada Kematian neonatal

\begin{tabular}{|c|c|c|c|c|c|c|}
\hline \multirow{3}{*}{ Variabel } & \multicolumn{4}{|c|}{ Kematian neonatal } & \multirow{3}{*}{$\mathbf{P}$} & \multirow{3}{*}{ OR (IK 95\%) } \\
\hline & \multicolumn{2}{|c|}{$\begin{array}{c}\text { Dini } \\
(n=82)\end{array}$} & \multicolumn{2}{|c|}{$\begin{array}{l}\text { Lanjut } \\
(\mathrm{n}=21)\end{array}$} & & \\
\hline & $n$ & $\%$ & $\mathbf{N}$ & $\%$ & & \\
\hline $\begin{array}{l}\text { Umur ibu } \\
-\quad<20 \text { tahun } \\
-\quad 20-35 \text { tahun } \\
-\quad>35 \text { tahun }\end{array}$ & $\begin{array}{c}19 \\
54 \\
9\end{array}$ & $\begin{array}{c}18,45 \\
52,42 \\
8,74\end{array}$ & $\begin{array}{c}9 \\
11 \\
1\end{array}$ & $\begin{array}{c}8,74 \\
10,68 \\
0,97\end{array}$ & 0,81 & $\begin{array}{l}0,744(0,223-2,477) \\
0,342(0,024-4,810)\end{array}$ \\
\hline $\begin{array}{ll}\text { Pendidikan ibu } \\
\text { - } & \text { Dasar } \\
\text { - } & \text { Menengah } \\
\text { - } & \text { Tinggi }\end{array}$ & $\begin{array}{l}60 \\
19 \\
3\end{array}$ & $\begin{array}{c}58,25 \\
18,45 \\
2,91\end{array}$ & $\begin{array}{c}16 \\
4 \\
1\end{array}$ & $\begin{array}{l}15,53 \\
3,88 \\
0,97\end{array}$ & 0,54 & $\begin{array}{c}0,475 \\
(0,118-1,909) \\
<0,001\end{array}$ \\
\hline $\begin{array}{l}\text { Pekerjaan ibu } \\
\text { - } \quad \text { Tidak bekerja } \\
\text { - } \quad \text { Bekerja }\end{array}$ & $\begin{array}{l}64 \\
19\end{array}$ & $\begin{array}{l}62,13 \\
18,45\end{array}$ & $\begin{array}{c}2 \\
19\end{array}$ & $\begin{array}{c}1,94 \\
18,45\end{array}$ & 0,28 & $\begin{array}{c}0,55 \\
(0,147-2,080)\end{array}$ \\
\hline
\end{tabular}

Tabel 1 menunjukkan kematianan terbanyak pada usia neonatus dini (0-7 hari) yang berjumlah 82 orang $(79,6 \%)$. Hasil analisis karakteristik ibu yaitu faktor umur $(P=0,81)$, pendidikan $(P=0,54)$ dan pekerjaan $(\mathrm{P}=0,28)$, nilai $\mathrm{p}$ lebih dari 0,05 . Sehingga tidak menunjukkan hubungan yang bermakna dengan kematian neonatus Sedangkan hubungan antara faktor-faktor yang mempengaruhi kematian neonatal seperti paritas, tempat persalinan, penolong, status rujukan, jenis persalinan, dan penyebab dengan kematian neonatal digambarkan pada 
tabel berikut:

Tabel 2. Hubungan berbagai faktor terhadap Kematian neonatal

\begin{tabular}{|c|c|c|c|c|c|c|}
\hline \multirow{3}{*}{ Variabel } & \multicolumn{4}{|c|}{ Kematian neonatal } & \multirow[t]{3}{*}{$\mathbf{P}$} & \multirow[t]{3}{*}{ OR (IK 95\%) } \\
\hline & \multicolumn{2}{|c|}{$\begin{array}{c}\text { Dini } \\
(n=82)\end{array}$} & \multicolumn{2}{|c|}{$\begin{array}{l}\text { Lanjut } \\
(\mathrm{n}=21)\end{array}$} & & \\
\hline & $n$ & $\%$ & $n$ & $\%$ & & \\
\hline $\begin{array}{l}\text { Paritas } \\
\text { - Primi para } \\
\text { - Multi para } \\
\text { - Grande multipara }\end{array}$ & $\begin{array}{c}39 \\
38 \\
5\end{array}$ & $\begin{array}{c}37,86 \\
36,89 \\
4,85 \\
\end{array}$ & $\begin{array}{c}14 \\
6 \\
1\end{array}$ & $\begin{array}{c}13,59 \\
5,82 \\
0,97 \\
\end{array}$ & 0,04 & $\begin{array}{c}0,74 \\
(0,106-1,197) \\
1,01(0,059-17,164) \\
\end{array}$ \\
\hline $\begin{array}{l}\text { Tempat persalinan } \\
\text { - Fasilitas } \\
\text { Kesehatan } \\
\text { - Fasilitas Non } \\
\text { kesehatan }\end{array}$ & $\begin{array}{l}69 \\
13\end{array}$ & $\begin{array}{l}66,99 \\
12,62\end{array}$ & $\begin{array}{c}18 \\
3\end{array}$ & $\begin{array}{l}17,47 \\
2,91\end{array}$ & 0,28 & $\begin{array}{c}0,88 \\
(0,227-3,441)\end{array}$ \\
\hline $\begin{array}{l}\text { Status Rujukan } \\
\text { - Rujukan } \\
\text { - Non Rujukan } \\
\end{array}$ & $\begin{array}{l}44 \\
38 \\
\end{array}$ & $\begin{array}{l}42,71 \\
36,89 \\
\end{array}$ & $\begin{array}{c}8 \\
13 \\
\end{array}$ & $\begin{array}{c}7,77 \\
12,62 \\
\end{array}$ & 0,25 & $\begin{array}{c}1,98 \\
(0,740-5,278) \\
\end{array}$ \\
\hline $\begin{array}{l}\text { Penolong } \\
\text { Persalinan } \\
\text { - } \quad \text { Tenaga } \\
\quad \text { Kesehatan } \\
\text { - } \quad \text { Tenaga Non } \\
\quad \text { Kesehatan } \\
\end{array}$ & $\begin{array}{l}80 \\
2\end{array}$ & $\begin{array}{r}77,66 \\
1,94\end{array}$ & $\begin{array}{l}20 \\
1\end{array}$ & $\begin{array}{c}19,42 \\
0,97\end{array}$ & 0,49 & $\begin{array}{c}2,00 \\
(0,173-23,176)\end{array}$ \\
\hline $\begin{array}{l}\text { Jenis Persalinan } \\
\text { - Spontan } \\
\text { - Tindakan }\end{array}$ & $\begin{array}{l}18 \\
64\end{array}$ & $\begin{array}{l}17,47 \\
62,13\end{array}$ & $\begin{array}{c}4 \\
17\end{array}$ & $\begin{array}{c}3,88 \\
16,50\end{array}$ & 0,52 & $\begin{array}{c}0,84 \\
(0,250-2,801)\end{array}$ \\
\hline $\begin{array}{l}\text { Penyebab } \\
\text { - Langsung } \\
\text { - Tidak langsung }\end{array}$ & $\begin{array}{l}66 \\
16\end{array}$ & $\begin{array}{l}64,01 \\
15,53\end{array}$ & $\begin{array}{l}11 \\
10\end{array}$ & $\begin{array}{l}10,67 \\
9,71\end{array}$ & 0,01 & $\begin{array}{c}2,87 \\
(1,038-7,920)\end{array}$ \\
\hline
\end{tabular}

Pengujian secara bivariat dengan uji Chisquare dapat diketahui bahwa dari enam faktor yang diteliti, terdapat dua faktor yang secara bermakna berhubungan dengan kematian neonatus yaitu paritas dan penyebab dengan nilai $p<0,05$. Sebagian besar kematian terjadi pada neonatus dini (0-7 hari) sejumlah 82 orang $(79,61 \%)$. Usia neonatal dini sangatlah rentan terhadap kejadian kematian neonatus, sehingga diperlukan perawatan yang rutin dan menyeluruh. Keadaan bayi waktu lahir dipengaruhi oleh keadaan bayi sewaktu dalam rahim, terutama selama persalinan dan kelahiran yang penuh dengan tekanan. Keadaan pada saat lahir bervariasi dari bayi normal yang menangis dan aktif sampai bayi yang sama sekali tidak memberi respon dan mungkin meninggal jika tidak segera diberikan resusitasi. Karena itu, penyedia layanan kebidanan dan perawatan bayi baru lahir harus siap (dengan tenaga terlatih, perlengkapan yang sesuai dan obatobatan yang diperlukan) untuk memberikan pertolongan darurat dan 
perawatan secara menyeluruh untuk bayi baru lahir (Benson \& Martin, 2009).

Kematian neonatal pun dapat terjadi pada saat umur ibu dalam masa reproduksi., sehingga seharusnya seorang ibu harus tetap waspada terhadap kehamilannya karena setiap kehamilan pun mengandung resiko. Kehamilan merupakan kondisi krisis yang dialami oleh perempuan tidak hanya gangguan pada psikologis namun juga adanya perubahan sense dan identitas pada diri perempuan. Pada perempuan dewasa, perubahan ini sama sekali tidak berhenti namun menjadi masalah yang cukup besar jika terjadi pada remaja. Anak yang lahir dari ibu dengan usia yang terlalu muda atau terlalu tua mempunyai risiko kematian dan gangguan kesehatan jangka panjang yang lebih besar dari anak lainnya (Lubis, 2008).

Penelitian ini menunjukkan adanya hubungan signifikan antara paritas dan kematian neonatus nilai $p<0,05$ Jumlah paritas ibu hamil merupakan salah satu faktor predisposisi terjadinya kelahiran premature karena jumlah paritas dapat mempengaruhi keadaan kesehatan ibu dalam kehamilan. Kategori rawan hanya berlaku pada kehamilan anak pertama.(Israr, 2007). Faktor paritas ibu merupakan determinan antara yang mempengaruhi terjadinya kematian neonatal, faktor determinan dekat mungkin lebih dominan berpengaruh terhadap terjadinya kematian neonatal seperti komplikasi ibu pada saat kehamilan dan persalinan antara lain ketuban pecah dini yang memudahkan terjadinya infeksi pada bayi, perdarahan pervaginam yang terjadi pada kehamilan sebelum 3 dapat menyebabkan abortus, perdarahan yang terjadi pada kehamilan trimester ke-3 meskipun hanya sedikit merupakan ancaman bagi janinnya, hipertensi dalam kehamilan dapat menyebabkan pertumbuhan janin terhambat sehingga bayi lahir dengan BBLR, infeksi berat dalam kehamilan akan berakibat terjadinya kematian janin dalam kandungan, distosia, persalinan macet dan persalinan tak maju dapat menyebabkan terjadinya infeksi pada bayi dan bayi lahir dengan asfiksia (Depkes, 2001) Ibu hamil yang memiliki risiko tersebut akan meningkatkan risiko terjadinya komplikasi pada neonatus seperti asfiksia, BBLR dan infeksi yang merupakan penyebab utama terjadinya kematian neonatal (Noorhalimah, 2015). Menurut Efriza (2007) risiko kematian neonatal dini yang besar pada bayi yang dilahirkan dari ibu dengan paritas 1 disebabkan oleh kekakuan jaringan panggul serta pengetahuan tentang perawatan kehamilan dan persalinan yang rendah. Pada ibu dengan paritas $>4$, kematian neonatal dini dapat disebabkan oleh kemunduran elastisitas jaringan yang sudah berulang kali berkontraksi pada saat persalinan sehingga membatasi kemampuan menghentikan pendarahan. $\mathrm{Hal}$ ini dapat menyebabkan pendarahan 
hebat pada saat persalinan dan membawa risiko pada kematian bayi.

Penelitian ini menghasilkan faktor penyebab baik langsung dan tidak langsung berkaitan dengan kematian neonatus. Penyebab kematian langsung sejumlah 77 kasus $(74,76 \%)$. Hal ini menggambarkan bahwa semakin muda usia neonatus semakin rentan terjadinya kematian dengan permasalahan penyakit yang dialami bayi dalam fase-fase awal kehidupannya. Kematian neonatus dapat terjadi karena beberapa faktor, adapun beberapa penyakit penyebab langsung yang dapat mengganggu kelangsungan kehidupan neonatal antara lain terjadinya SGNN (Sindrom Gawat Nafas Neonatus), Asfiksia Neonatorum, Bayi Berat Lahir Rendah (BBLR), Trauma Kelahiran dan Kelainan Bawaan serta adapun penyakit penyebab tidak langsung yang dapat biasanya terjadi setelah beberapa hari kemudian bayi itu lahir antara lain sepsis dan tetanus neonatorum (Lubis, 2008; Kemenkes RI, 2010; Saifuddin, 2007.

Depkes RI (2001) menjelaskan penyebab kematian bayi dapat bermula dari masa kehamilan 28 minggu sampai hari ke-7 setelah persalinan (masa perinatal). Penyebab kematian bayi yang terbanyak adalah karena pertumbuhan janin yang lambat, kekurangan gizi pada janin, kelahiran prematur dan berat bayi lahir rendah, yaitu sebesar 38,85\%. Penyebab lainnya yang cukup banyak terjadi adalah kejadian kurangnya oksigen dalam rahim (hipoksia intrauterus) dan kegagalan nafas secara spontan dan teratur pada saat lahir atau beberapa saat setelah lahir (asfiksia lahir), yaitu $27,97 \%$. Hal ini menunjukkan bahwa 66,82\% kematian neonatal dihubungkan pada kondisi ibu saat melahirkan. Penurunan kematian neonatal sangat ditentukan oleh penatalaksanaan kesehatan ibu pada saat kehamilan, menjelang persalinan dan setelah persalinan. Hasil penelitian WHO menunjukan bahwa $10 \%$ dari kematian neonatus berkaitan dengan masa intra partum.(Lawn, at all, 2005)

Kematian bayi tidak hanya tergantung dari faktor pencegahan dan pengobatan penyakit. Anak sakit yang luput dari kematian akan hidup tetapi terganggu pertumbuhan tubuhnya, sehingga antara kematian dan status gizi anak adalah dua peristiwa yang tidak dapat dipisahkan (Wilopo, 1990). Kedua peristiwa penting ini dipengaruhi oleh faktor sosial-ekonomi secara tidak langsung melalui Lima faktor utama (determinan), yaitu: 1) faktor maternal; 2) kontaminasi lingkungan; 3) defisiensi nutrisi; 4) kecelakaan; dan 5) faktor pencegahan dan pengobatan terhadap penyakit. Kualitas penduduk yang menjadi rendah, didukung dengan angka kesakitan yang juga tinggi, terutama penyakit infeksi menular. Kondisi lingkungan yang kurang mendukung menjadi salah satu faktor yang mempengaruhi rendahnya derajat kesehatan. Faktor lainnya adalah tingkat sosial ekonomi masyarakat yang rendah, pendidikan yang kurang dan 
penyediaan lapangan pekerjaan yang tidak memadai.(Prasetya, 2015)

Perlunya

upaya

dengan

memperbaiki cakupan pelayanan neonatus dengan meningkatkan keterampilan penolong persalinan dan untuk memastikan akses terhadap perawatan obstetrik darurat. Intervensi kesehatan untuk memperbaiki perawatan neonatal sangat penting dan perilaku mencari perawatan juga diperlukan, terutama untuk neonatus prematur pada periode pascakelahiran awal. (Baqui at all, 2006). Perlu upaya yang lebih lanjut dari berbagai pihak bukan saja pemerintah tetapi juga masyarakat dan pihak swasta supaya ikut berperan serta dalam menurunkan angka kematian neonatus.

\section{KESIMPULAN}

Berdasarkan hasil penelitian maka dapat disimpulkan beberapa hal sebagai berikut sebagian besar ditemukan pada Neonatal dini sejumlah 82 orang $(79,6 \%)$, tidak ditemukan hubungan yang bermakna antara umur ibu, pendidikan ibu, pekerjaan ibu, status rujukan, tempat persalinan, jenis persalinan, penolong persalinan dengan kematian neonatus. Faktor paritas dan penyebab langsung menjadi faktor yan bermakna sebagai penyebab kematian neonatus.

\section{DAFTAR PUSTAKA}

Kemenkes RI. 2014. Profil Kesehatan Indonesia Tahun 2013. Jakarta

Kemenkes. 2011. Profil Kesehatan Indonesia Tahun 2010. Jakarta

Lawn. 2005. Million Neonatal Dead When? Where? Why?

Benson \& Martin. 2009. Buku Saku

Obstetri dengan Gynekologi. Buku Kedokteran EGC. Jakarta

Lubis, C.P. 2008. Infeksi Nosokomial Pada Neonatus Bagian Kesehatan Anak. FK USU

Saifuddin. 2007. Buku Acuan Nasional Pelayanan Kesehatan Maternal dan Neonatal. Yayasan Bina Pustaka Sarwono Prewirohardjo. Jakarta

Manuaba, 2007. IImu Kebidanan, Penyakit Kandungan dan Keluarga Berencana. EGC. Jakarta

Kemenkes. 2010. Panduan Pelayanan Kesehatan Bayi Baru Lahir Berbasis Perlindungan Anak. Dinkes Anak Khusus. Jakarta

Noorhalimah, 2015. Faktor-Faktor Yang Berhubungan Dengan Kematian Neonatal Di Kabupaten Tapin. Jurnal Publikasi Kesehatan Masyarakat Indonesia; Vol 2 no 2

Naetasi JE, Mariana Dinah C, Masrida S, 2009. Faktor-Faktor yang Berhubungan dengan Kematian Neonatal Di Kota Kupang Tahun 2009. Jurnal MKM; Vol 6 No.2

Joy Lawn,Kenji Shibuya, \& Claudia Stein. 2005. No cry at birth: global estimates of intrapartum stillbirths and intrapartum-related neonatal deaths Bulletin of the World Health Organization June 2005

Prasetya B, 2015. Upaya Penurunan Kematian Bayi pada MDG's. FKM Universitas Jember.

Baqui AH,GL Darmstadt, EK Williams, V Kumar,TU Kiran, D Panwar, VK Srivastava, R Ahuja, RE Black and M Santosham. 2006. Rates, timing and causes of neonatal deaths in rural India: implications for neonatal health programmes.WHO. 